\title{
PENGURANGAN KOROSI DIBAWAH FIRE PROOFING DENGAN METODE PRIMER COATING
}

\author{
Sulardi \\ Sekolah Tinggi Teknologi Migas, Balikpapan \\ Email : sulardikm61@yahoo.com
}

\begin{abstract}
ABSTRAK
Tujuan penelitian adalah untuk memberikan gambaran penentuan spesifikasi material primer coating dan metode aplikasinya untuk pengendalian korosi dibawah fireproofing sstruktur pipe rack dan struktur penopang peralatan di industri kilang pengolahan minyak. Target yang ingin dicapai dari penelitian ini adalah tersedianya spesifikasi material primer coating dan kemudahan aplikasinya pada struktur pipe rack dan struktur penopang peralatan industri kilang pengolahan minyak. Penelitian ini adalah metode penelitian aplikatif dengan pendekatan studi kasus yaitu dalam rangka mengatasi masalah korosi dibawah fire proofing. Diduga penyebab korosi dibawah fireproofing adalah karena didalam spesifikasi proyek kilang tidak terdapat ketentuan aplikasi primer coating dibawah fireproofing. Asumsi yang dikembangkan dalam menjawab permasalahan penelitian adalah dengan tersedianya spesifikasi material dan metode aplikasi primer coating dibawah fire proofing maka korosi dibawah fireproofing dapat dikendalikan dan dikurangi. Spesifikasi material primer coating dengan service temperature $(-45)^{\circ} \mathrm{C}-(650)^{\circ} \mathrm{C}$ dengan material coating hi-built epoxy, epoxy phenolic, epoxy nonov, inargonic copolimer dan multi polymetric matrix, telah memenuhi spesifikasi teknis NACE SP 0198-2010 dan metode aplikasi primer coating dengan variasi ketebalan primer coating adalah 100-200 micron (dry film thicness) DFT, terbukti cocok dan sesuai digunakan untuk mengendalikan masalah korosi dibawah fire proofing. Hasil penelitian ini juga merekomendasikan bahwa sesifikasi material dan metode aplikasi primer coating yang telah disusun didalam pedoman primer coating yang telah sesuai spesifikasi NACE SP 0198-2010 dapat dijadikan sebagai standar baku.
\end{abstract}

Kata kunci : Korosi dibawah fireproofing, struktur pipe rack, penopang peralatan kilang 


\section{PENDAHULUAN}

\section{Latar Belakang}

Struktur pipe rack dan struktur penopang peralatan kilang memiliki peran penting menunjang operasional kilang industri pengolahan minyak. Struktur pipe rack menopang sistim perpipaan dari satu satu peralatan ke peralatan lain dan satu proses ke proses selanjutnya. Demikian pula struktur penopang peralatan kilang memiliki fungsi penting menopang peralatan industri kilang sehingga peralatan dapat berfungsi dengan baik dan aman. Struktur pipe rack dan struktur penopang peralatan yang terbuat dari baja profil dengan dimensi tertentu, dibentuk sedemikian rupa sehingga dapat berdiri tegak diatas pondasi dan dapat menopang jalur perpipaan (pipe rack) dan peralatan kilang dengan baik. Dalam rangka pemenuhan regulasi standar keselamatan industri kilang pengolahan Migas maka struktur pipe rack dan struktur penopang peralatan kilang diproteksi dengan material pelindung yang resistance terhadap paparan panas, yang selanjutnya dikenal dengan material fire proofing. Material fire proofing dipasang menyelimuti struktur pipa rack dan struktur penopang peralatan sehingga pada saat terjadi paparan api kebakaran masih tersedia waktu untuk penyelamatan. Dalam hal terjadi incident kebakaran kecil atau kebakaran lokal maka fire proofing akan melindungi struktur baja terpasang sehingga struktur baja tidak mengalami kerusakan atau kegagalan secara dini.

Merujuk kepada data Project Specification X1 Rev.4 Bechtel International: Pertamina Balikpapan Refinery Expansion Project tahun 1982 dan Data Project Specification JGC: General Spesification for Painting, Doc. No. PS-250- 13A1-001-E Rev R1, Pertamina Balikpapan Refinery I Upgrading Project tahun 1994, keberadaan struktur pipe rack dan struktur penopang peralatan kilang diproteksi dengan fire proofing berbahan dasar beton (dense concrete) atau beton ringan (light concrete) dengan tebal terpasang $5 \mathrm{Cm}$.

Permasalahan yang dihadapi adalah terjadinya korosi dibawah pasangan fire proofing (corrosion under fire proofing/ CUF) yang mengakibatkan struktur fire proofing mengalami retak-retak, rompal dan kerusakan struktur baja pipe rack. Kondisi ini dikategorikan sebagai kondisi sub stabdard dan unsafe condition yang merupakan salah satu temuan asuransi terkait keselamatan operasional kilang

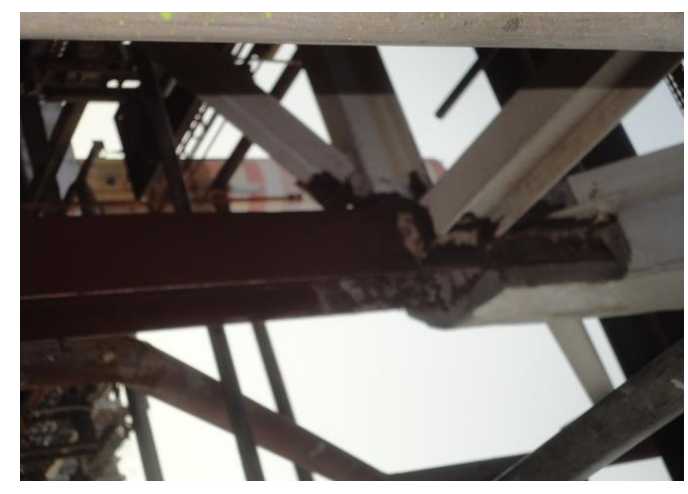

Gambar 1. Korosi dibawah fire proofing (Corrosion under fier proofing)

Korosi adalah bentuk degradasi material permukaan metal akibat metal berada pada kondisi lembab, terekspos bebas dan terkontaminasi dengan lingkungan udara bebas (oksidasi). Hasil penelusuran menemukan bahwa berdasarkan Project Specification X-1 Rev.4 Bechtel International: Pertamina Balikpapan Refinery Expansion Project, 1982 dan Data Project Specification JGC: General Spesification for Painting, Doc. No. PS-250- 13A1001-E Rev R1, Pertamina Balikpapan Refinery I Upgrading Project, 1994, struktur baja pipe rack dan struktur penopang peralatan yang diproteksi dengan fire proofing tidak diproteksi dengan primer coating. Pada awalnya hal tersebut bukanlah merupakan permasalahan, namun setelah digunakan 10 tahun mulailah ada indikasi dan tanda-tanda terjadi retakretak, laminasi dan spalling pasangan fire proofing. Dari hasil uji hole test pada lokasi retak, laminasi dan spalling diketahui bahwa logam dibawah fire proofing tidak diproteksi dengan pimer coating dan kondisi permukaannya lembab. Dengan demikian diyakini bahwa penyebab korosi dibawah fire proofing adalah logam struktur pipe rack dan penopang peralaan kilang tidak diproteksi dengan primer coating.

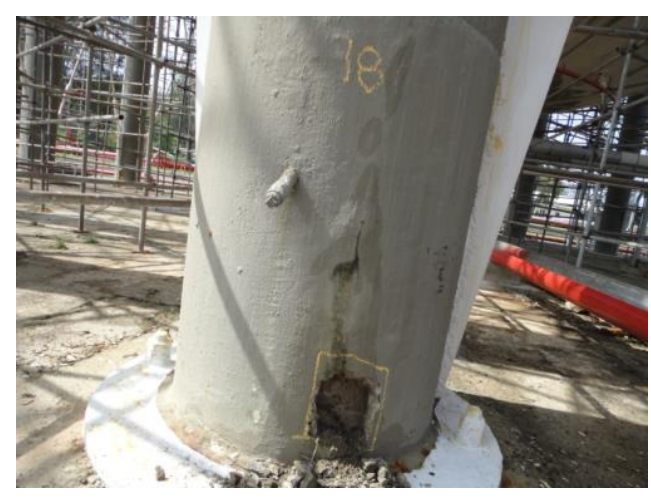

Gambar 2. Uji hole test korosi dibawah fireproofing 
Terhadap permasalahan tersebut telah dilakukan upaya perbaikan dengan mengganti struktur pipe rack dan struktur penopang peralatan yang rusak terkorosi dengan baja profil baru dan melapis dengan primer coating. Namun hal ini tidak menyelesaikan permasalahan karena permasalahan korosi dibawah fire proofing masih tetap terjadi dan berpotensi merusak pipe rack dan struktur penopang peralatan operasi dan produksi kilang. Berdasarkan data temuan permasalahan, hasil uji hole test, penyebab permasalahan dan data spesifikasi tersebut diatas maka penelitian ini penting untuk dilakukan guna menemukan jawaban atas pertanyaan mengapa korosi dibawah fire proofing tersebut terjadi dan bagaimana upaya pencegahan yang dilakukan seperti melapis dan melindungi permukaan logam baja struktur pipe rack dan struktur penopang peralatan operasi kilang dengan primer coating sebelum baja struktur dicover dengan fire proofing.

\section{Rumusan Masalah}

Rumusan yang akan dikembangkan pada penelitian adalah sebagai berikut.

a. Korosi dibawah fire proofing (CUF) adalah degradasi permukaan material logam akibat permukaan logam yang terekspos mengalami kontak dengan kondisi lembab dibawah insulasi

b. Korosi dibawah fire proofing disebabkan oleh peristiwa oksidasi permukaan logam dengan lingkungan lembab dibawah fire proofing.

\section{Asumsi Penelitian}

Asumsi yang akan dikembangkan dalam penelitian ini adalah sebagai berikut.

a. Korosi dibawah firefroofing adalah peristiwa alamiah yang tidak dapat dicegah, namun dapat ditekan atau dikurangi terjadinya

b. Salah satu upaya menekan terjadinya korosi dibawah fireproofing adalah dengan memasang lapisan penghambat (barier effect) berupa lapisan primer coating

c. Jika lapisan penghambat (barier effect) promer coating berfungsi dengan baik maka oksidasi permukaan logam dan korosi dibawah fireproofing tidak akan terjadi.

\section{Tujuan Penelitian}

Tujuan yang hendak dicapai melalui kegiatan penelitian ini adalah untuk :

a. Memberikan gambaran penentuan spesifikasi material primer coating dibawah fireproofing pada struktur pipe rack dan struktur penopang peralatan kilang

b. Memberikan gambaran aplikasi primer coating dibawah fireproofing pada struktur pipe rack dan struktur penopang peralatan kilang.

\section{Manfaat Hasil Penelitian}

Manfaat hasil penelitian aplikasi ini adalah sebagai berikut.

a. Keberhasilan penerapan pelapisan primer coting untuk mencegah korosi dibawah fire proofing pada struktur pipe rack dan struktur penopang peralatan industri kilang pengolahan Migas

b. Success story technical notes sebagai sharing knowledge di Sekolah Tinggi Teknologi (STT) Migas Balikpapan

c. Publikasi ilmiah hasil penelitian di jurnal internal/ eksternal Sekolah Tinggi Teknologi (STT) Migas Balikpapan

d. Pengembangan bahan ajar dan pengkayaan khasanah kepustakaan dalam bidang peralatan industri kilang pengolahan minyak dan gas bumi di Sekolah Tinggi Teknologi (STT) Migas Balikpapan

\section{KAJIAN PUSTAKA}

Korosi dibawah fire proofing (corrosion under fire proofing) adalah kerusakan yang dihasilkan dari reaksi kimia antara sebuah logam atau logam paduan dan didalam suatu lingkungan. Fenomena korosi merupakan reaksi kimia yang dihasilkan dari dua reaksi setengah sel yang melibatkan elektron sehingga menghasilkan suatu reaksi elektrokimia. Dari dua reaksi setengan sel ini terdapat reaksi oksidasi pada anoda dan reaksi reduksi pada katoda. Kebanyakan proses korosi bersifat elektrokimia, dimana larutan berfungsi sebagai elektrolit sedangkan anoda dan katoda terbentuk karena adanya inhomogenitas. Beberapa faktor lingkungan yang dapat mempengaruhi proses korosi, diantaranya 
adalah (1) Suhu, dimana adanya kenaikan suhu akan menyebabkan bertambahnya kecepatan reaksi korosi. Hal ini terjadi karena makin tinggi suhu maka energi kinetik dari partikel-partikel yang bereaksi akan meningkat sehingga melampaui besarnya harga energi aktivasi dan akibatnya laju kecepatan reaksi (korosi) juga akan makin cepat, begitu juga sebaliknya (2) kecepatan alir fluida atau kecepatan pengadukan. Laju korosi cenderung bertambah jika laju atau kecepatan aliran fluida bertambah besar. Hal ini karena kontak antara zat pereaksi dan logam akan semakin besar sehingga ion-ion logam akan makin banyak yang lepas sehingga logam akan mengalami kerapuhan (3) konsentrasi bahan korosif, hal ini berhubungan dengan $\mathrm{pH}$ atau keasaman dan kebasaan suatu larutan. Larutan yang bersifat asam sangat korosif terhadap logam dimana logam yang berada didalam media larutan asam akan lebih cepat terkorosi karena karena merupakan reaksi anoda. Sedangkan larutan yang bersifat basa dapat menyebabkan korosi pada reaksi katodanya karena reaksi katoda selalu serentak dengan reaksi anoda (4) Oksigen, dimana adanya oksigen yang terdapat di dalam udara dapat bersentuhan dengan permukaan logam yang lembab. Sehingga kemungkinan menjadi korosi lebih besar. Di dalam air (lingkungan terbuka), adanya oksigen menyebabkan korosi (5) waktu kontak antara logam dengan lingkungan penyebab korosi.

Korosi dibawah fireproofing terjadi karena adanya kabut (uap air) atau pengembunan, dapat mengakibatkan terjadinya korosi karena udara bersifat lembab dan basah dengan embun yang tetap berada ditempat sampai dengan adanya tekanan angin atau kenaikan temperatur yang dapat memindahkannya. Serangan korosi dibawah insulasi dimulai dimulai dengan terbentuknya selapis tipis uap air yang tidak tampak secara visual pada kelembaban, > 60\%. Jika kelembaban $>80 \%$ maka karat yang terbentuk dan baja akan bersifat menyerap air (higroskopik) dan dari sinilah serangan korosi dibawah insulasi berlanjut. Laju korosi dibawah insulasi dalam kondisi tanah basah memiliki kecepatan korosi 20 kali kebih besar dibandingkan pada korosi atmosferik (ambeint). Karena secara visual tidak terlihat, maka korosi dibawah insulasi (CUI) seakan-akan terjadi secara mendadak dan dapat mengakibatkan terjadinya kebocoran pipa, kebocoran peralatan kilang, bahaya semburan fluida, flash dan kebakaran terlebih jika perpipaan atau peralatan dioperasikan pada temperatur dan tekanan tinggi.

Tiga faktor penyebab korosi dibawah fireproofing adalah (1) faktor adanya uap air yang berasal selama penyimpanan material insulasi atau pada saat pemasangan insulasi, karena kebocoran sistim, karena tidak baikanya sistim water proofing dan perawatan sistim insulasi yang baik (servie lapses) (2) kandungan bahan kimia dalam air. Bila $\mathrm{pH}$ air berada <4 maka korosi akan berlangsung dengan cepat, seperti korosi asam (acidic corrosion) umumnya yang terjadi pada material carbon steel, sehingga perlu dijaga (maintenance) agar kondisi $\mathrm{pH}$ material insulasi berada pada kondisi $\mathrm{pH}$ netral, yakni pada $\mathrm{pH}$. 7,0-11,7 (3) temperatur operasi atau temperatur lingkungan.

Pengendalian korosi dibawah fire proofing dengan pelapisan coating adalah salah satu cara yang dianggap cocok dan sesuai untuk pengendalian korosi adalag dengan cara memasang lapisan perlindungan material logam terhadap pengaruh lingkungan dengan metode pelapisan coating (coating protection). Pelapisan ini metode pelapisan eksternal. Metode pelapisan (external protection) dipandang lebih memungkinkan dan lebih mudah dilakukan dibandingkan metode proteksi yang dilakukan dari sisi dalam pipa. Hal ini didasarkan pada kenyataan bahwa bocornya pipa dibawah insulasi dominannya akibat kerusakan yang berasal dari korosi dibagian luar pipa. Lapisan cat (coatings) pada dasarnya adalah larutan dispersi yang dapat diubah menjadi material padat yang relatif cahaya setelah digunakan sebagai pelapis tipis pada permukaan bahan logam. Pelapisan bertujuan untuk memberikan lapisan padat dan merata sebagai bahan isolator atau penghambat aliran listrik diseluruh permukaan logam yang dilindungi. Fungsi lapisan tersebut adalah untuk mencegah logam mengalami kontak langsung dengan elektrolit dan lingkungan disekitarnya sehingga reaksi logam dan lingkunga disekitarnya terhambat.

Fungsi coating dalam melindungi material logam yang dilindunginya (coating system) meliputi (1) shop primer berfungsi sebagai proteksi sementara (2) primer coat berfungsi sebagai basic coat/cat dasar dengan daya lekat yang baik (3) intermediate coat, berfungsi untuk menciptakan ketebalan dan sifat kedap air, dan (4) top/ finish coat berfungsi sebagai fungsi dekoratif dan external protection. Adapun cara coating memproteksi material yang diproteksinya adalah dengan cara (1) memberikan barrier effect, yaitu dengan menjadikan lapisan coating sebagai lapisan pemisah antara lingkungan dan logam yang dilindunginya (2) inhibitor effect, yaitu dengan membentuk lapisan passive untuk mencegah masuknya korosi (3) galvanic 
effect, yaitu dengan menjadikan coating sebagai anoda korban.

\section{METODE PENELITIAN}

\section{Metode Pendekatan}

Penelitian ini adalah penelitian terpakai (application research) dengan metode pendekatan studi kasus, yakni studi kasus penanganan masalah korosi dibawah insulasi (corrosion under insulation) pada sistim perpipaan dan peralatan operasi di kilang PT. Pertamina RU V Balikpapan.

\section{Bahan Penelitian}

Spesifikasi material primer coating disesuaikan dengan jenis material logam yang akan diproteksi dengan primer coating, meliputi material carbon steel (CS), alloy steel (AS) dan stainless steel (SS).

\section{Peralatan}

Peralatan pembersihan permukaan yang akan dicoating (grade cleanlines) pada preparasi coating sesuai surface preparation standards and specification (SSPC) sebagai berikut.

a. SSPC SP-1, adalah peralatan surface preparation berupa solvent cleaning, yaitu persiapan permukaan dengan menggunakan larutan (air, larutan detergent, MEK, dan sejenisnya) sebagai media pembersih permukaan

b. SSPC SP-2, adalah peralatan surface preparation berupa hand Tools, yaitu proses persiapan permukaan dengan menggunakan peralatan kerja manual (peralatan tangan ringan) seperti abrasive paper, hampelas, kape dan sejenisnya

c. SSPC SP-3, adalah peralatan surface preparation berupa power tools, yaitu proses persiapan permuka an dengan menggunakan peralatan mesin untuk membersihkan kotoran dan membentuk profile

d. SSPC SP-10, adalah peralatan surface preparation berupa abrasive blasting, yaitu proses persiapan permukaan menggunakan material abrasive blasting (dry abrasive or wet abrasive) untuk menghilangkan kotoran dan rust di permukaan metal serta membuat profile dipermukaan metal

\section{Prosedur Aplikasi Primer Coating}

a. Aplikasi coating harus memenuhi kondisi lingkungan sebagai berikut :

1) Relative humadity $<85 \%$, terkecuali untuk spesifikasi inorganic zinc silicate $<90 \%$

2) Temperatur permukaan $3^{\circ} \mathrm{C}$ diatas dew point

b. Preparasi permukaan yang akan di aplikasikan primer coating dilakukan preparasi sesuai stnadrad berikut.

1) SSPC SP-1, surface preparation berupa solvent cleaning, yaitu persiapan permukaan dengan menggunakan larutan sebagai media pembersih permukaan

2) SSPC SP-2, menggunakan hand Tools, yaitu proses persiapan permukaan dengan menggunakan peralatan kerja manual seperti abrasive paper, hampelas, kape dan sejenisnya sehingga permukaan siap coating

3) SSPC SP-3, menggunakan power tools, yaitu proses persiapan permuka an dengan menggunakan peralatan mesin untuk membersihkan kotoran dan membentuk profile

4) SSPC SP-7, menggunakan brush off blast cleaning

5) SSPC SP-11, menggunakan power tools cleaning to bare metal

6) SSPC SP-6, menggunakan comercial blast cleaning

7) SSPC SP-10, pembersihan menggunakan blasting hingga near white blast cleaning

8) SSPC SP-5, pembersihan menggunakan blasting hingga white metal blast cleaning

c. Spesifikasi material untuk blasting adalah angular steel grit, alumunium oxide dan dust free mineral abrasive, tidak boleh menggunakan material pasir silika

d. Hasil pekerjaan surface preparation dilaporkan tertulis kepa owner dalam bentuk berita acara pemeriksaan dan untuk dapat melanjutkan aplikasi coating didasarkan atas tanda tangan persetujuan

e. Sebelum aplikasi coating dilakukan pengukuran temperatur udara ambeint, untuk spesifikasi epoxy coating adalah $10^{\circ} \mathrm{C}$ dan untuk toping dengan acryl polyuretahane adalah $5^{\circ} \mathrm{C}$

e. Pemastikan kondisi dew point, relative humadity, temperature ambeint dan temperatur substrate, dicatat dalam log book $2 x$ pershift

f. Selama aplikasi coating, pelaksana harus memeriksa ketebalan coating dan melaporkan kepada owner 
g. Toleransi ketebalan coating dan frekwensi pengukuran ketebalan coating harus mengacu kepada standar

h. Aplikator harus memastikan bahwa aplikasi coating tidak ada cacat berupa orange peel, pinholes, cracking, run and sags, bubbling dan bistering

i. Stripe coat harus diaplikasi dengan kuas pada semua sudut, detail sisi yang tajam, baut dan rivet dengan spesifikasi coating yang sama

j. Jika terjadi defect maka harus dilakukan perbaikan sebelum aplikasi coating pada lapis selanjutnya dan pada bagian tepi harus dilebih luasannya $50 \mathrm{~mm}$

k. Aplikator harus menyiapkan benda uji (pre qualification test/ $\mathrm{PQT}$ ) untuk setiap coating material pada setiap substrate dan material panel harus dengan luas area panel minimal. $225 \mathrm{Cm}^{2}$

1. Dalam pre qualification test (PQT) harus telah dijelaskan persyaratan kondisi lingkungan, material dan setting peralatan, profil permukaan, tingkat kebersihan permukaan, visual coating dan uji adhessive.

\section{HASIL DAN PEMBAHASAN}

Hasil penentuan spesifikasi material logam jenis carbon steel (CS) sistim perpipaan dan peralatan operasi kilang serta ketebalan lapisan coating berdasarkan jenis logam carbon steel yang diproteksi sebagaimana tersaji pada tabel.1.

Tabel 1. Spesifikasi primer coating untuk logam carbon steel (CS)

\begin{tabular}{|l|c|l|}
\hline Jenis Material Logam & $\begin{array}{c}\text { Temperatur Permukaan } \\
\left({ }^{\circ} \mathrm{C}\right)\end{array}$ & \multicolumn{1}{|c|}{$\begin{array}{c}\text { Base Type Prime Coat } \\
(\mu \mathrm{m})\end{array}$} \\
\hline Carbon Steel (CS) & $-45 \mathrm{~s} / \mathrm{d} 60$ & Hi-built Epoxy $(130)$ \\
\hline Carbon Steel (CS) & $-45 \mathrm{~s} / \mathrm{d} 150$ & Epoxy Phenolic (150) \\
\hline Carbon Steel (CS) & $-45 \mathrm{~s} / \mathrm{d} 205$ & $\begin{array}{l}\text { Epoxy Novolac/Silicone } \\
\text { Hybrid }(100-200)\end{array}$ \\
\hline Carbon Steel (CS) & $-45 \mathrm{~s} / \mathrm{d} 595$ & $\begin{array}{l}\text { Thermal Spray Alumunium } \\
(\text { TSA })(250-350)\end{array}$ \\
\hline Carbon Steel (CS) & $-45 \mathrm{~s} / \mathrm{d} 650$ & $\begin{array}{l}\text { Inorganic Copolimer/ Multi } \\
\text { polymetric Matrix } \\
(100-150)\end{array}$ \\
\hline $\begin{array}{l}\text { Carbon Steel (CS) } \\
\text { Galvanized Fire Proofing }\end{array}$ & Ambeint & $\begin{array}{l}\text { Epoxy/ Epoxy Phenolic } \\
(100-150)\end{array}$ \\
\hline
\end{tabular}

Tabel 2. Spesifikasi primer coating untuk logam Alloy steel dan Stainless steel

\begin{tabular}{|l|c|l|}
\hline Jenis Material Logam & $\begin{array}{c}\text { Temperatur Permukaan } \\
\left({ }^{\circ} \mathrm{C}\right)\end{array}$ & \multicolumn{1}{|c|}{$\begin{array}{c}\text { Base Type Prime Coat } \\
(\mu \mathrm{m})\end{array}$} \\
\hline SS/ Alloy Steel & $-45 \mathrm{~s} / \mathrm{d} 60$ & Hi-built Epoxy $(125-175)$ \\
\hline SS/ Alloy Steel & $-45 \mathrm{~s} / \mathrm{d} 150$ & Epoxy Phenolic $(100-150)$ \\
\hline SS/ Alloy Steel & $-45 \mathrm{~s} / \mathrm{d} 205$ & Epoxy Novolac $(100-200)$ \\
\hline SS/ Alloy Steel & $-45 \mathrm{~s} / \mathrm{d} 650$ & $\begin{array}{l}\text { Inorganic Copolimer/ Multi } \\
\text { polymetric Matrix }(100-150)\end{array}$ \\
\hline
\end{tabular}

Spesifikasi material primer coating dibawah fire proofing berdasarkan service temperature, mulai dari $-45^{\circ} \mathrm{C}$ sampai dengan $650^{\circ} \mathrm{C}$. Service temperatur ini menentukan jenis material coating yang digunakan meliputi hi-built epoxy, epoxy phenolic, epoxy nonov dan inargonic copolimer/ multi polymetric matrix, yakni ketahanannnya untuk tidak rusak terhadap pengaruh temperatur. Variasi ketebalan primer coating adalah 100-200 micron DFT, tergantung service temperatur dan base type prime coat yang digunakan. Fungsi lapisan coating dalam melindungi material logam yang dilindunginya (coating system) meliputi (1) shop primer coating yang berfungsi sebagai proteksi sementara (2) primer coating yang berfungsi sebagai basic coating atau cat dasar dengan daya lekat yang baik (3) intermediate coat yang berfungsi untuk menciptakan ketebalan dan sifat kedap air, dan (4) top atau finish coat yang akan berfungsi sebagai fungsi dekoratif dan external protection.

Setelah diaplikasikan maka lapisan primer coating akan memproteksi material logam yang diproteksinya dengan cara (1) memberikan barrier effect, yaitu dengan menjadikan lapisan coating sebagai lapisan pemisah antara lingkungan dan logam yang dilindunginya (2) memberikan inhibitor effect, yaitu dengan membentuk lapisan passive untuk mencegah masuknya serangan korosi, dan (3) memberikan galvanic effect, yaitu dengan menjadikan lapisan coating sebagai anoda korban.

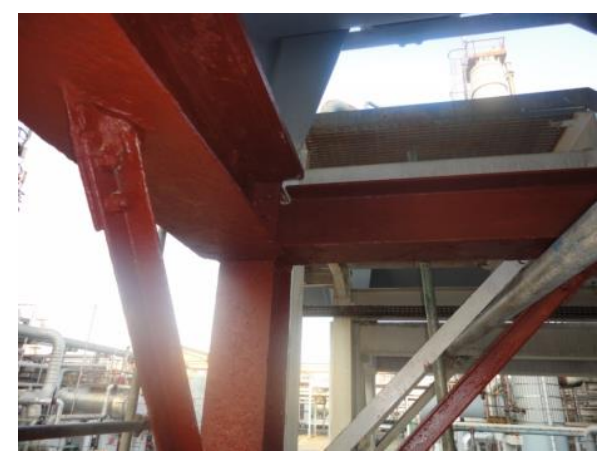

Gambar 3. Aplikasi primer coating dibawah Fire proofing struktur pipe rack

Kunci sukses aplikasi coating dibawah fire proofing adalah terletak pada baiknya persiapan permukaan (good surface preparation) adalah adalah persiapan permukaan yang baik, yaitu (1) permukaan yang akan dicoating memiliki kekasaran permukaan yang cukup dan sesuai (surface profile), dan (2) permukaan yang akan dicoating bersih dari rust/ karat, kotoran, pervious paint / coating eksisting, dirt $\&$ dust (kotoran dan debu), oil \& grease (minyak dan 
lemak), salt (garam) dan sisa-sisa fabrication detail. Kunci suses lain yang harus menjadi perhatian adalah parameter aspek lingkungan yang harus diuji sesuai standard ASTM E 337-15 yang meliputi ambient temperatur berupa wet bulb temperature dan dry bulb temperature, dw point, relative humidity, surface temperature dan wind velocity.

\section{PENUTUP}

\section{Kesimpulan}

a. Spesifikasi material primer coating dengan service temperature $(-45)^{\circ} \mathrm{C}-(650)^{\circ} \mathrm{C}$ dengan material coating hi-built epoxy, epoxy phenolic, epoxy nonov, inargonic copolimer dan multi polymetric matrix, telah memenuhi spesifikasi teknis NACE SP 0198-2010

b. Metode aplikasi primer coating dengan variasi ketebalan primer coating adalah 100-200 micron (dry film thicness) DFT, terbukti cocok dan sesuai digunakan untuk mengendalikan masalah korosi dibawah fire proofing.

\section{Saran}

a. Spesifikasi material dan metode aplikasi primer coating yang telah disusun didalam pedoman primer coating yang telah sesuai spesifikasi NACE SP 0198-2010 dapat dibakukan sebagai standar baku

b. Metode aplikasi pengendalian korosi dibawah fire proofing dengan metode primer coating di PT. Pertamina RU V dapat direplikasi untuk mengatasi permasalahan sejenis diluar Pertamina.

\section{Ucapan Terimakasih}

Dengan selesainya penelitian ini kami mengucapkan terimakasih kepada Bapak Kurniawan Dahri dari Stationary Inspection Engineer PT. Pertamina RU V Balikpapan yang banyak membantu dalam penentuan spesifikasi material primer coating dan metode aplikasinya. Terimakasih juga kepada kawan-kawan dari Asosiasi Korosi Indonesia (INDOCOR) yang telah banyak membantu, mereview spesifikasi dan sekaligus mensupervisi aplikasi primer coating yang kami lakukan.

\section{DAFTAR PUSTAKA}

ASTM D-4541, (2012), Standard Test For Pull-off Stength Of Coating Using Portable Adhesion Tester, ASTM International

ASTM E 337-15, (2015), Stadard Test Method for Measuring Humadity With A Psychrometer(The Measurement of Wet and Dry Bulb Temperatures, ASTM International

ISO 8501-1 Part 1, Rust Grades and Preparation Grades of Uncoated Steel Subtrates and Steel Substrates After Overall Removal of Previous Coating

ISO 8501-1 Part 2, Visual Assessment of Surface Cleanliness

ISO 8501-1 Part 3, Preparation Welds, Cut Edges and Other Areas With Surface Imperfection

Muftia, Haqi. Askan., dkk., (2011), Analisa Kegagalan Pada Pipa Elbowa 234-WPB Akibat Korosi Di Bawah Insulasi, Jurnal Intake, Vol. 2, Nomor 2, Oktober 2011

NACE SP 0198-2010, Control Of Corrosion Under Thermal Insulation and Fire Proofing Material- A System Approach

Project Specification X-1 Rev.4, (1982), Bechtel International: Pertamina Balikpapan Refinery Expansion Project, 1982

Project Specification JGC, (1994), General Spesification for Painting, Doc. No. PS-25013A1-001-E Rev R1, Pertamina Balikpapan Refinery I Upgrading Project.

Pujowidodo, Hariyotejo. Nuryadin, Bhakti. (2015), Evaluasi Kinerja Insulasi dan Kerusakan CUI Pipa Distribusi Uap Unit Utility Plant Pengolahan Minyak, Prosiding SNST ke-6 Tahun 2015, Fakultas Teknik Universitas Wahid Hasyim Semarang

Sulardi, 2019, Peralatan Industri, Penerbit Nusa Litera Insipirasi, Kab. Cirebon, Jawa Barat

Sulardi, Kurniawan, D., (2015), Pedoman Coating Perpipaan dan Peralatan Kilang, PT. Pertamina RU V, Balikpapan 